\title{
ORIGIN OF THE LATE PALEOZOIC METAMORPHIC ROCKS IN EAST JOHOR, PENINSULAR MALAYSIA
}

\author{
Sugeng Sapto Surjono*1 and Mohd. Shafeea Leman ${ }^{2}$ \\ ${ }^{1}$ Department of Geological Engineering, Faculty of Engineering, Universitas Gadjah Mada, Indonesia \\ ${ }^{2}$ School of Environmental Science and Natural Resources, Universiti Kebangsaan Malaysia, Selangor, Malaysia
}

\begin{abstract}
Low grade metamorphic rocks including slate, phyllite, metasandstone with subordinate schist and quartzite are widely distributed in the East Johor, Peninsular Malaysia. Regionally, this rock unit is extended northward up to northern Terengganu area. The protolith of this rocks unit were deposited in shallow marine depositional environment that subsequently metamorphosed during Carboniferous time. The very thick argillaceous and arenaceous rocks more than 5000 metres were produced by fast rate accommodation spaces due to global sea level rise during Early to Late Carboniferous against with high fine-grained sediment supply. Tectonic setting, basin formation and sedimentation processes were controlled by rifting of IndochinaEast Malaya continental block from Gondwanaland during Devonian to Late Carboniferous. This rifting formed basins within a passive margin tectonic setting along the western margin of Indochina-East Malaya continental block.
\end{abstract}

Keywords: metamorphic rocks, shallow marine, Carboniferous, passive margin

\section{Introduction}

The metasedimentary to metamorphic rocks are broadly distributed in eastern Johor and southeastern Pahang, occupying over 50\% of Palaeozoic rocks distribution (Figure 11. Foo (1983)

\footnotetext{
*Corresponding author: SUGENG SAPTO SURJONO, Department of Geological Engineering, Faculty of Engineering, Universitas Gadjah Mada, Jl. Grafika 2, Yogyakarta 55281. E-mail: ssuryono@ugm.ac.id
}

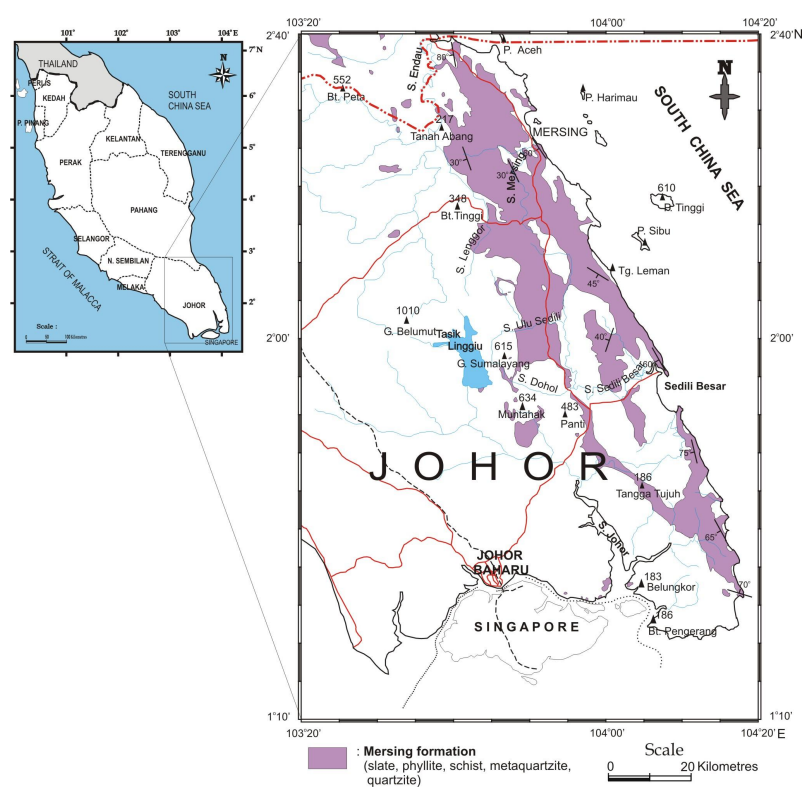

Figure 1: Distribution of metamorphic rocks (Mersing formation) in East Johor.

claimed that this rock unit is possibly equivalent to those in the northern part of Eastern Belt of Peninsular Malaysia including northern Pahang to Terengganu areas. In eastern Johor, this rock unit is outcropped mainly along the coastline, forming rocky beach landscape. It can be traced from the Tanjung Punggai in Pengerang area northward through Desaru, Sedili Besar and Mersing to Endau in northeastern most of Johor. To the west, this rock unit is bordered by eastern margin of Eastern Granitoid Province. In inland, this rock unit is usually expressed by the undulating to rolling lowland morphology. 
In the East Johor, the metamorphic rocks are believed as the oldest rocks that are unconformably overlain by siliciclastic and volcanic rocks. Drummond (1962) considered this rocks unit as the Carboniferous to Permian in age. Koopmans (1968) interpreted a Carboniferous age for this rocks unit based on the correlation with other metamorphic rocks along the coast of Peninsular Malaysia. Based on the geological map in southern Johor area, Grubb (1968) interpreted the age of this rock unit as pre-Carboniferous. Later, Metcalfe (2000) interpreted it and whole metasedimentary rocks in Eastern Belt of Peninsular Malaysia as Carboniferous in age. Hutchison (1989) considered that the metamorphic rock in the eastern Johor is as basement in this area. However, Liew and McCulloch (1985) and Metcalfe (2000) assumed that metasedimentary rocks in eastern block of Peninsular Malaysia were deposited overlying the unexposed Precambrian basement rocks.

The protolith of the rock unit in Pengerang area was interpreted by Grubb (1968) as sedimentary origin. Meanwhile, Cook and Suntharalingam (1969) also recognised the tuffaceous nature for some metasedimentary rocks in northern Johor and southern Pahang area. Foo (1983) inferred that this protolith was deposited in a shallow marine to mixed condition depositional environment. On the contrary, Suntharalingam (1991) interpreted this rock unit was a deep water clastic sediments, probably from eugeosynclinal environment.

\section{Lithology}

Metasedimentary to metamorphic rock in eastern Johor and southeastern Pahang was assigned into several informal lithostratigraphic nomenclatures. Cook and Suntharalingam (1969) named it as Mersing beds, while Suntharalingam (1991) classified this rock unit as Mersing group that include siliciclastic sediment of Dohol and Linggiu formations. Lately, Mohd Shafeea et al. (2003) proposed the name Mersing formation for the entire metamorphic to metasedimentary rocks distributed in East Johor. Surjono et al. (2006) retained the usage of Mersing formation for lithostratigraphy of metamorphic rock in eastern Johor and southeastern Pahang areas. This paper also uses this lithostratigarphic nomenclature for the mention rock unit. Up till now, this rock unit has never been formally described based on the Malaysian Stratigraphic Nomenclature Committee (MSNC, 1997).

In general, lithology of the Mersing formation consists of quartzite, metasandstone, schist, phyllite, slate and argillite. The rocks are usually black, dark to light grey in colour, sometimes showing rhythmic interbedding between arenaceous and argillaceous rocks. Thick to massive argillaceous rocks are also common particularly in inland area. In coastal areas, the beddings are sometimes truncated due to the intensive folding and faulting. Quartz veins and lenses are very common, cutting the slate, phyllite or schist bedset. Due to intense tectonic deformation, continuous successions of metasedimentary and metamorphic rocks are difficult to be traced, even within small outcrops.

Quartzite Quartzite and metasandstone are the most common arenaceous rock type within the Mersing formation. They are predominantly light grey, white or buff-coloured, sometimes iron-stained. It is mainly composed of quartz with subordinate lithic grains and mica. The textures are commonly mosaic (granoblastic) with grain to grain contact and sutured grain borders. Matrix is usually made up of fine-grained, siliceous or argillaceous material which is commonly contains sericite flake or micaceous chlorite. Lithic grain probably mudstone or argillite, occurs in black colour, rounded and sometimes amorphous form due to compaction. It is common in quartzite and metasandstone rock with distribution is less than $5 \%$.

The fresh rock is compact and hard but it may become a friable upon intense weathering. Some of the arenaceous rocks are however, rich in lithic clasts, and therefore did not immediately turn to quartzite at low degree of metamorphism and are classified into metasandstone to metasiltstone. Quartzite, metasandstone and metasiltstone commonly 
have medium thicknesses, between 10 and 30 $\mathrm{cm}$, rarely reaches up to $75 \mathrm{~cm}$, showing planar bedding to laminae structure (Figure $2 \mathrm{a}$, b). Other sedimentary structures include tabular cross bedding or cross lamination as well as hummocky cross bedding, lenticular and graded beddings also occur in limited distribution.

Schist Schist of the Mersing formation is commonly black to dark grey in colour and shows prominent foliation of flaky minerals and layered orientation of granular minerals. Schistosity texture is represented by foliation of chloritic mineral that sometimes can be observed in the field (Figure 2k). Schist usually shows intermixture of grains and foliation of flaky minerals with lepidoblastic texture where granular minerals tend to form layered orientation. Some of these granular mineral have undergone sericitization. Quartz dominates the mineral composition and most of them optically show undulatory extinction. Mica appears as dark brown, flaky minerals, mostly as biotite mixed with sericite and chlorite with minor muscovite. Sometimes mica becomes the dominant component of the rock. Lithic grains occur as black and dirty coloured, rarely distributed and possibly mixed with iron oxide stain. Sediment grains mainly exhibit point to long sometime suture contacts.

The foliation is generally parallel to the bedding, where large sized flaky minerals are arranged in organized orientations. There are two types of schist identified in Mersing formation, i.e., the quartz schist and mica schist. In the field, schists are commonly occurred in association with quartzite as interbedding strata. Quartzite and schist represent the highest degree of metamorphism found in the study area. In outcrops, these rocks are often very tight folded such as in Tanjung Kempit, Tanjung Balau and several other places along the coastline of East Johor.

Phyllite Phyllite is the most dominant rock in the Mersing formation. It is dark grey to black in colour, and commonly shows distinctive fracture cleavage with foliation is generally parallel to the bedding plane. The rock consists mainly of quartz, mica and lithic grains with point to long grain contact. Phyllite shows low schistosity, mostly represented by foliation of sericite, chlorite and other flaky minerals. It commonly shows lepidoblastic texture where granular minerals are weakly aligned.

Phyllite is usually more friable in nature than schist. Upon weathers, this rock tends to form very soft clay, in which the distinctive sericitic sheen of phyllite usually remains visible. In the field, this rock is commonly interbedded with metasandstone and quartzite (Figure 2d). Sedimentary structures such as planar bedding, cross-bedding or graded bedding are commonly preserved in this phyllite. Rare relict sedimentary structures including wave ripple cross-lamination and flaser bedding are also developed. The thickness of phyllite varies from few $\mathrm{cm}$ to $50 \mathrm{~cm}$. However, the bedsets of phyllite may reach tens meters thick. Quartz veins are common and sometime cut the foliation obliquely.

Slate Slate is also common in the Mersing formation mainly outcropped in the inland area. In fresh rocks, it is usually black, dark grey and light grey in colour, with well developed slaty cleavage. The foliation in slate is essentially made up of clay minerals. Granular component usually consists of quartz and lithic fragment of mudstone. The metamorphism of clay mineral to chlorite indicates a low-grade metamorphism with granular minerals is rarely aligned. Fracture cleavages are also sometimes observed. The thickness of slate can reach up to ten meters.

Slate is normally soft, friable and has low resistances against erosion, and thus it is rarely found in coastal area. In the inland area, the slate is usually weathered to shale, prone to erosion and often formed responsible in formation of landslides along the road and hillslope cuts. Folds, joints and quartz vein are very common features of the slate (Figure 2e). The quartzites sometimes occur as lenses with width and thickness range from few centimetres to few metres. Foliation is only visible in slate or shale layers with finer grain mineral 
ORIGIN OF THE LATE PALEOZOIC METAMORPHIC ROCKS IN EAST JOHOR, MALAYSIA
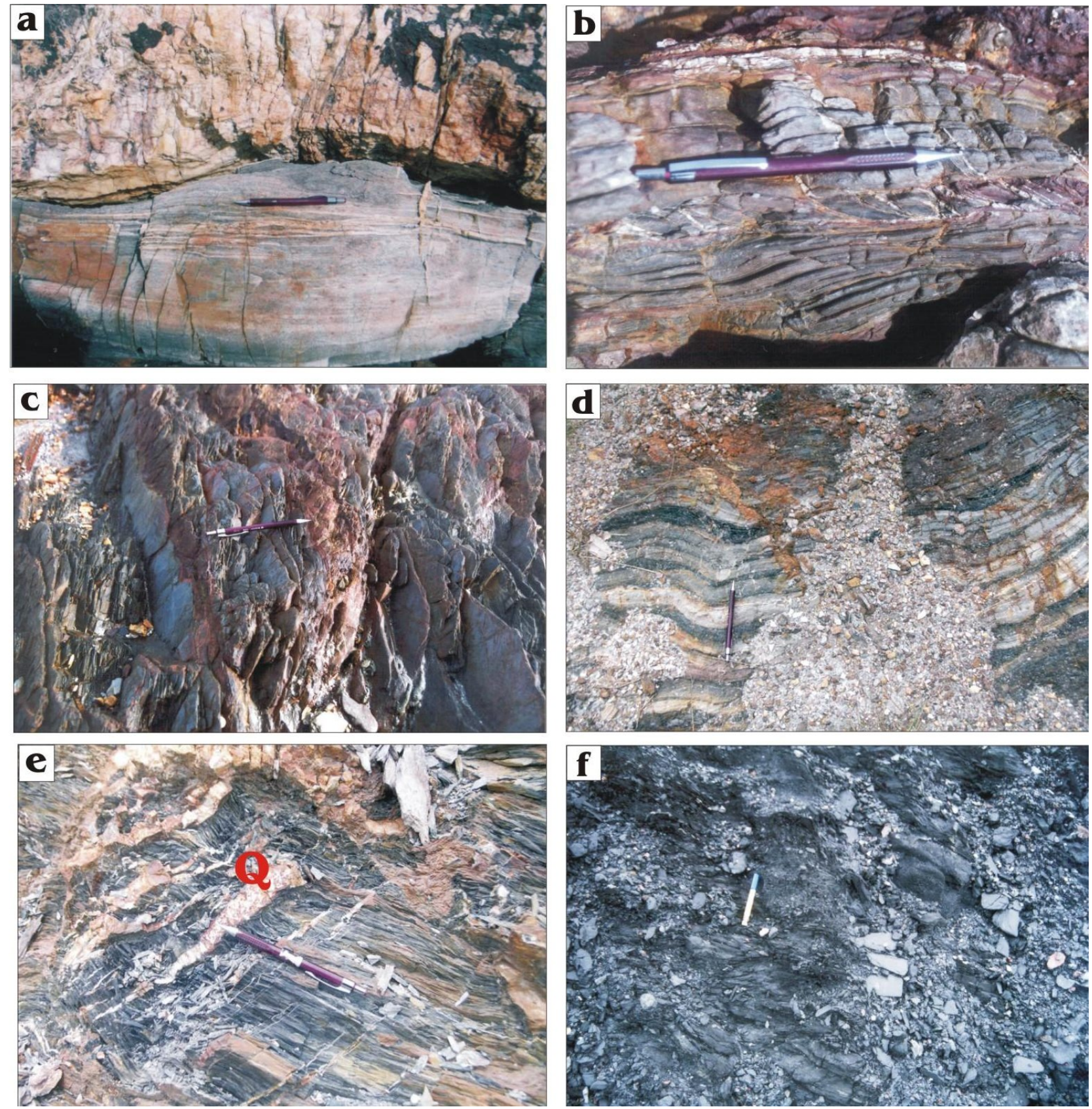

Figure 2: Representative rocks composing of the Mersing formation. (a) Bedded quartzite at Tanjung Kempit. (b) Metasandstone at Mersing coast (c) Chlorite schist at Sri Pantai, Mersing. (d) Interbedded of metasandstone-phyllite at Nitar. (e) Thick bedsets of slate with quartz vein (Q) at Desaru. (f) Thick bedsets of slate-argillite at Tanjung Sekakap. 


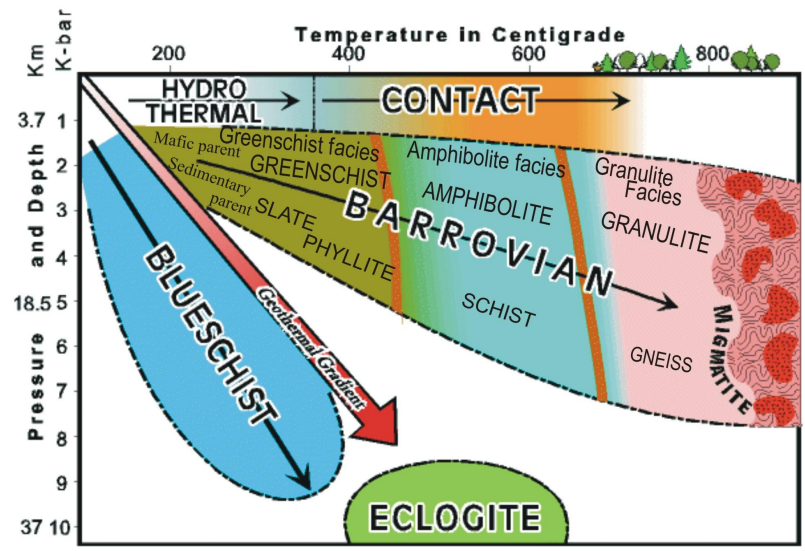

Figure 3: Metamorphic zone and facies (Fichter, 2000).

composition, while layers with slightly with coarser grain kept most of their distinctive sedimentary structures and textures (Figure 2f).

\section{Metamorphism}

In general, schist and quartzite are product of intermediate or medium grade, while metasandstone and phyllite are resulted by low grade Barrovian-type metamorphism (Miyashiro, 1994). This type of metamorphism takes place during mountain building events when very thick and large areas of sedimentary rocks are buried, squeezed and heated. Sometimes the metamorphism occurs just because the burial to deep enough, but often it is also associated with major igneous intrusions that supply most of the heat (Yardley, 1989). Regarding the time, regional metamorphism may take places between 10 and 50 million years to completely evolved (Bucher \& Frey, 1994). In the study area, metamorphic and metasedimentary rocks are dominated by slate, phyllite, schist and metasandstone. Such assemblage was most probably resulted from a low to intermediate grade Barrovian-type metamorphism of greenschist facies. Based on the metamorphic zone and facies (Figure 3), the range of this metamorphism may have occurred at the depth between 5 and $20 \mathrm{~km}$ with 2-6 k-bar pressure and temperature between 200 and 600 Centrigrade.

The occurrence of localized medium grade metamorphic rocks with schist and quartzite is dominant, such as in the Tanjung Kempit, Mersing Coast, Sedili Coast, Desaru, Tanjung Balau and Tanjung Punggai, may be affected by locally intensive geological deformation. This is in line with Raymond (1995)'s opinion that locally intensive dynamic metamorphism could increase metamorphic grade considerably. In such areas, metamorphic rocks may have undergone multiple generation of folds and faults. These phenomena had been described in detail by Chakraborty \& Metcalfe (1984), Mustaffa et al. (1999), Tajul Anuar \& Mustaffa (1999) and Harminzar et al. (2006).

\section{Depositional Environment}

The depositional environment of Mersing formation has been interpreted by several researchers. Foo (1983) inferred as a shallow marine to mixed conditional depositional environment for the oldest sediment in the eastern belt, supposedly including the Mersing formation. On the other hand, Hutchison (1989) interpreted this basement rock to be of distal turbidite origin. Suntharalingam (1991) also interpreted that this rock unit was a result of metamorphism upon deep water clastic sediments, probably from eugeosynclinal environment.

At a glance, the lower sequence of Mersing formation that comprises rhythmically interbedded of metasandstone-phyllite (Figure 4) perhaps resembles sedimentary rocks of turbidite succession normally deposited in deep marine environment as demonstrated by Mutti (1992). However, detail investigation on the successions, lithology and sedimentary structures of the Mersing sequence rather indicates shallow marine deposits. The general fining upward sequence in this sequence with numerous linear, thin sandstone bodies, cross-stratified and interbedded sandstone is similar to the shallow marine transgressive sequences. With this regard, the Mersing sequence is closely similar to that described by Davis (1992) for the shallow marine Tocito Sandstone of New Mexico. The domination of quartz, with subordinate amount of rock frag- 
ments and feldspar also generally indicated shallow marine terrigenous sediments (Davis, 1992; Pettijohn et al., 1987).

Investigation on relict structures within the metasandstone also indicates that the rocks were deposited in shallow sea. Compared to the interpretation of sedimentary structure carried out by Boggs (1992), the occurrence of sedimentary structure including wave ripple cross-lamination (Figure 5p), hummocky crossstratification (Figure $5 \mathrm{~b}$ ), tabular cross-bedding (Figure 5k) and lenticular bedding within shale (Figure 5 $\mathrm{d}$ ) suggests that the lower sequence of Mersing formation was deposited in shallow marine to perhaps lacustrine environment. Such sedimentary structures were interpreted by Johnson and Baldwin (1996) to be associated with storm-dominated processes in a shallow marine environment. Davis (1992) claimed that hummocky cross-stratification appear to be restricted to the shoreface between the normal and storm wave base. Based on the above description and interpretation, the most probable depositional environment of the lower sequence Mersing formation are shallow marine to coastal plane or lacustrine. Referring to palaeocurrent directions, source of the Mersing formation should be located in the east, whereas more argillaceous deeper marine sediment should be deposited to the west.

\section{Provenance}

Liew and McCulloch (1985) and Metcalfe (2000, 2002) interpreted a possible existence of Precambrian basement for the Indochina-East Malaya continental blocks (Kontum Massif). It presumably consists of metamorphic rocks of granulite facies that may have originally formed part of the Gondwanaland granulite belt. This basement could be the source for the Mersing formation and all metasedimentary rocks in the Eastern Belt of Peninsular Malaysia. However, the abundant of quartz in the metamorphic rocks of Mersing formation suggest that the source of sediments should have come from a craton, rather than a metamorphic rock. Petrographic and chemical analysis carried out by Surjono (2007) shows that quartz mineral usually formed more than $75 \%$ the bulk and silica content exceed $90 \%$. This quartz may be originated from the East Malaya continental block itself.

\section{Basin Evaluation}

The present day geology of Peninsular Malaysia is believed to be a final product of collision-suturing between Sibumasu and Indochina-East Malaya continental blocks during the formation of Southeast Asian Mainland (Metcalfe, 1999). In the Peninsular Malaysia, these continental blocks were sutured at the Bentong-Raub Suture Line (Hutchison, 1975). This line represents the remnant of subduction zone of the Palaeo-Tethys Ocean into the Indochina-East Malaya terranes which was followed by the collision between the Sibumasu and Indochina-East Malaya terranes. This subduction was initiated in the latest Early Carboniferous time, and the collision may have been started sometime in the Early Triassic and continues to Late Triassic times (Metcalfe, 2000).

According to Metcalfe (1999), since Devonian up to Early Carboniferous times, the East Malaya continental block was drifted northward in association with spreading of PalaeoTethys oceanic basin. This condition formed a passive western margin of East Malaya blocks (Figure 6). The deposition of Mersing formation in Johor occurred during this time together with similar rocks composing of the Panching formation and Sungai Perlis beds in North Kuantan and Terengganu. Palaeocurrent of Mersing formation is relatively westward (Surjono 2007), indicating source rocks was located in the east. The East Malaya proto-continent had probably been exposed to sub-aerial environment that underwent rapid weathering processes due to tropical climatic condition since the Late Devonian time. According to Metcalfe $(1999,2000)$, during Late Devonian to Late Permian, East Malaya-Indochina continental block was located near the equator. Prolonged weathering processes would have been responsible in providing enormous siliciclastic material for the Mersing formation. Concerning the abun- 


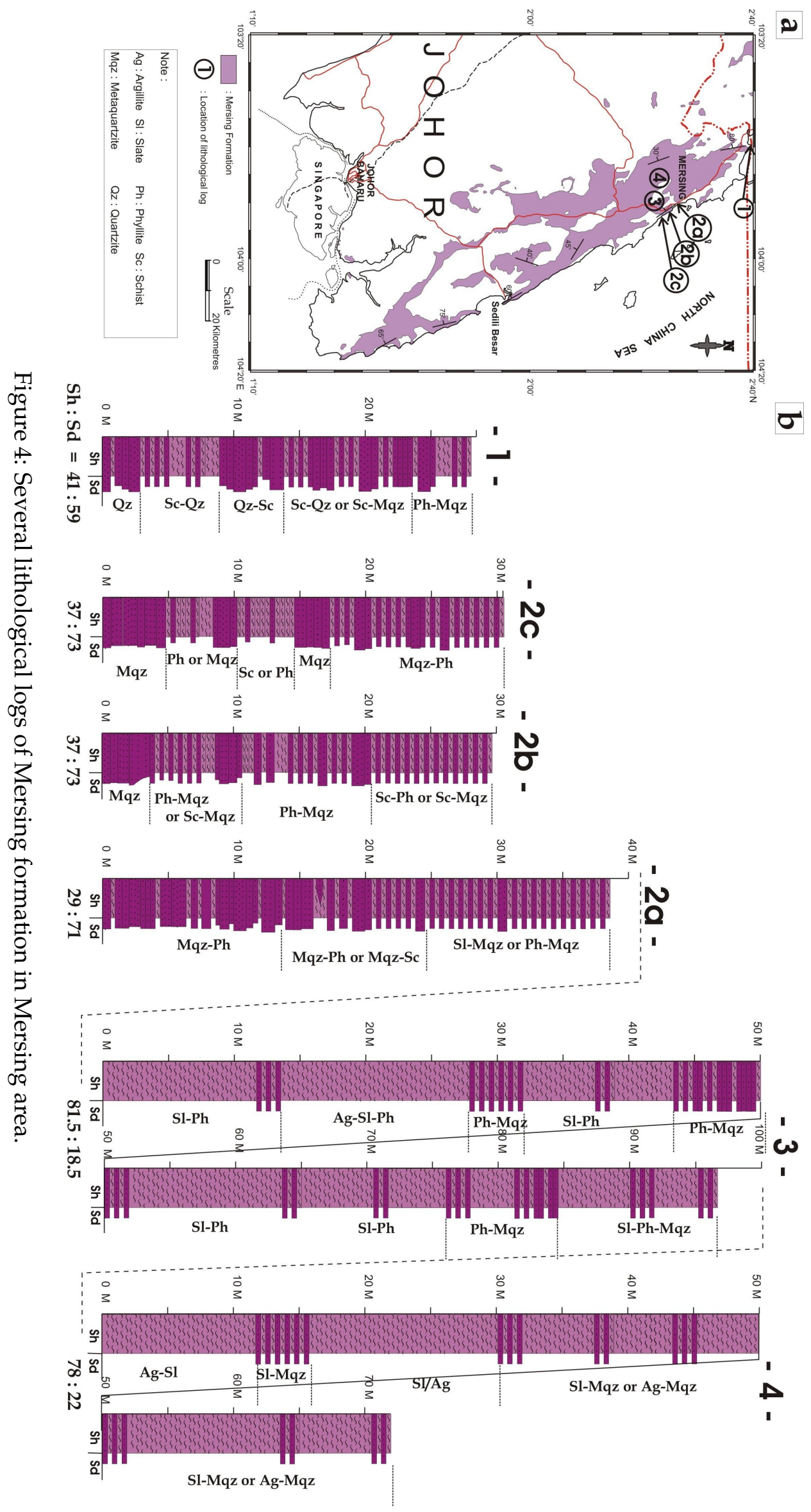



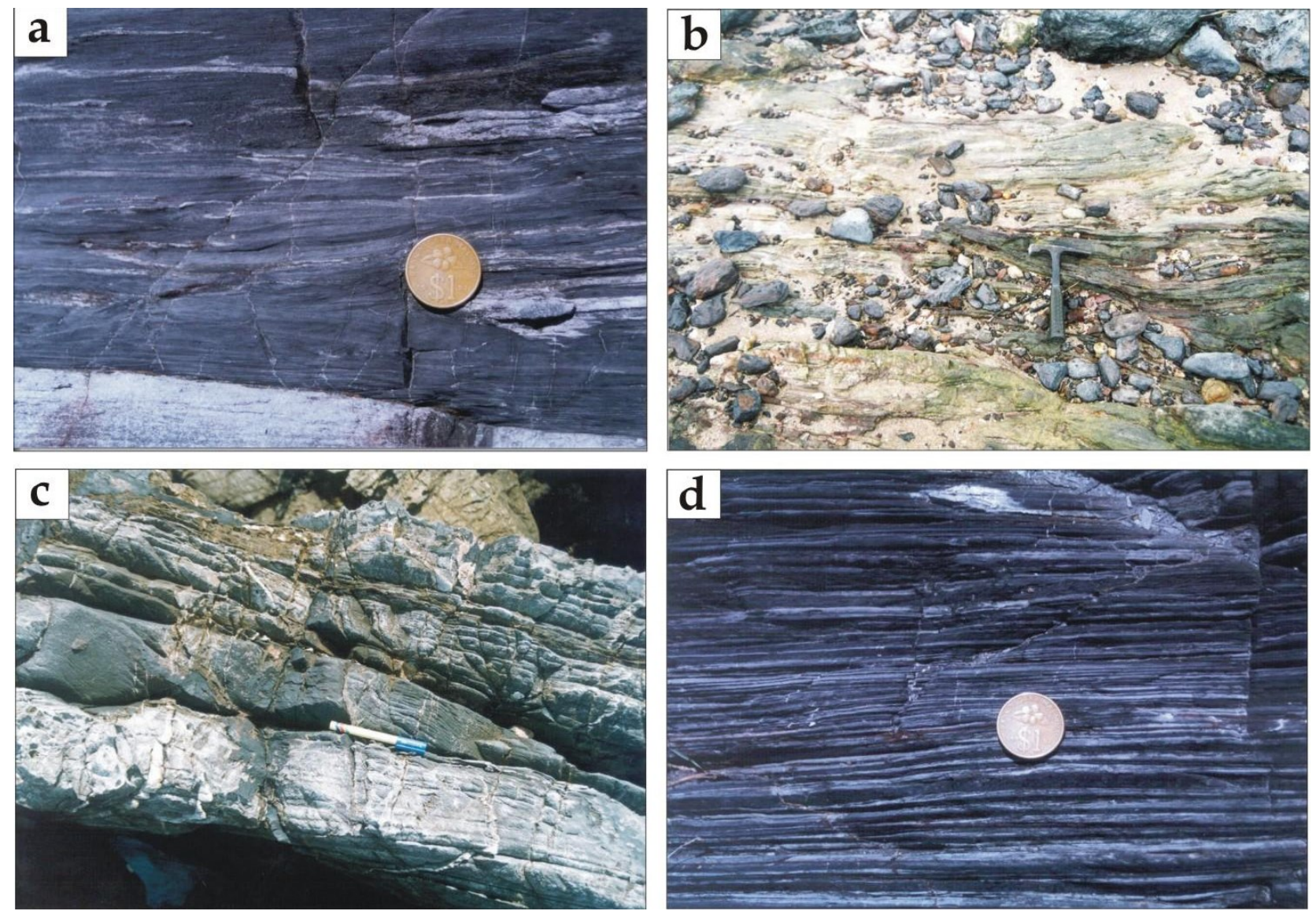

Figure 5: Relicts sedimentary structures of Mersing formation indicated shallow marine depositional environments products. (a) Wave ripples cross-lamination at Sedili Besar Coast. (b) Hummocky cross-stratification at Tanjung Punggai. (c) Tabular cross-bedding at Tanjung Balau. (d) Remains of lenticular bedding within interlaminated of sandstone and shale at Sedili Besar Coast. 
dant of fine-grained clasts within this formation, these clasts should have been transported from long distance area. Very thick succession of argillaceous rocks consisting of interbedded sandstone, siltstone and shale in Mersing formation is produced by deposition of high sediment supply into transgressive shallow marine depositional environment. The sedimentary process occurred in relatively fast rate accommodation spaces against with high sediment supply conditions. Transgressive phase during its deposition is indicated by generally fining upward succession of Mersing formation (Figure 4). Rough estimation on the thickness of Mersing formation based on the bedding plane and lateral distribution may reach up to 5,000 metres. This trangressive phase may be correlated with the global sea rise during Early to Late Carboniferous (Basir, 1999).

During the Late Carboniferous, Mersing formation was regionally metamorphosed due regional deformation and Late Carboniferous granites intrusion. These granites and it associated volcanic rocks were produced by partial melting of East Malaya continental block that was pushed out into Mersing formation (Figure 7). These deformation and metamorphism were generated by compressed of Palaeo-Tethys oceanic plate to Indochina-East Malaya continental plate. Burial of very thick sediment composing of Mersing formation is also considered as an important factor for increasing pressure in that metamorphism. Volcanic rocks may be deposited in the upper part of Mersing formation contemporaneously with deformation process. At this time Indochina-East Malaya continental blocks have accreted to South China forming the more static Cathaysialand continent. As consequence, the Palaeo-Tethys pushed the Cathaysialand to initiate the subduction (Figure 7).

\section{Conclusions}

The origin of Mersing formation is argillaceous and arenaceous rocks that were deposited in a shallow marine depositional environment within passive margin tectonic setting. This tectonic setting formed due to spreading of
Palaeo-Tethyian Ocean and northward drifting of Indochina-East Malaya continental blocks during Devonian to Early Carboniferous times. Those siliciclastic rocks were metamorphosed regionally during Late Carboniferous resulted low grade metamorphic rocks including slate, phyllite, metasandstone, schist and quartzite.

\section{Acknowledgement}

The field and laboratory works were carried out due to financial support of the Malaysian Ministry of Science, Technology and Environment through the IRPA 02-02-02-0012-EA186 grant. Authors thanks to institution mentioned above.

\section{References}

Basir Jasin. 1999. Significant of radiolarian chert in the northwestern zone of Peninsular Malaysia. Dynamic stratigraphy and tectonic of Peninsular Malaysia -Seminar II: the Western Belt and Palaeozoic of Peninsular Malaysia. pp. 1-19.

Boggs, S. Jr. 1992. Petrology of sedimentary rocks. New York: Macmillan Publishing Co.

Bucher, K. \& Frey, M. 1994. Petrogenesis of metamorphic rocks. 6th ed. Berlin: Springer-Verlag.

Chakraborty, K.R. \& Metcalfe, I. 1984. Analysis of mesoscopic structures at Mersing and Tanjung Kempit, Johore, Peninsular Malaysia. Geological Society of Malaysia Bulletin 17: 357-371.

Cook, R.H. \& Suntharalingam, T. 1969. Geological Recconnaissance Area " $\mathrm{C}$ ", North Johore-South Pahang-concluding phase. Geological Survey of Malaysia Annual Report 1969. pp 82-93.

Davis, Jr., R.A. 1992. Depositional system: an introduction to sedimentology and stratigraphy. 2nd ed. New Jersey: Prentice-Hall.

Drummond, P.C.V. 1962. Progress report on geological work done in Sheet 131, South Johore. Geological Survey of Malaysia Professional Papers E63-2G: 28-32.

Fichter, L.S. 2000. Metamorphic rocks. (on line). http://csmres.jmu.edu/geollab/Fichter/ MetaRx /index.html. (July 01, 2005).

Foo, K,Y. 1983. The Paleozoic Sedimentary Rocks of Peninsular Malaysia-Stratigraphy and Correlation. Proc. Workshop on Stratigraphic Correlation of Thailand and Malaysia 1: 1-19.

Grubb, P.L.C. 1968. Geology and Bauxite Deposits of the Pengerang area, southeast Johor. Geological Survey of West Malaysia District Memoir 14.

Harminzar Mansor, Ibrahim Abdullah, Azirul Liana Abdullah, Jatmika Setiawan \& Mohd Syukri 


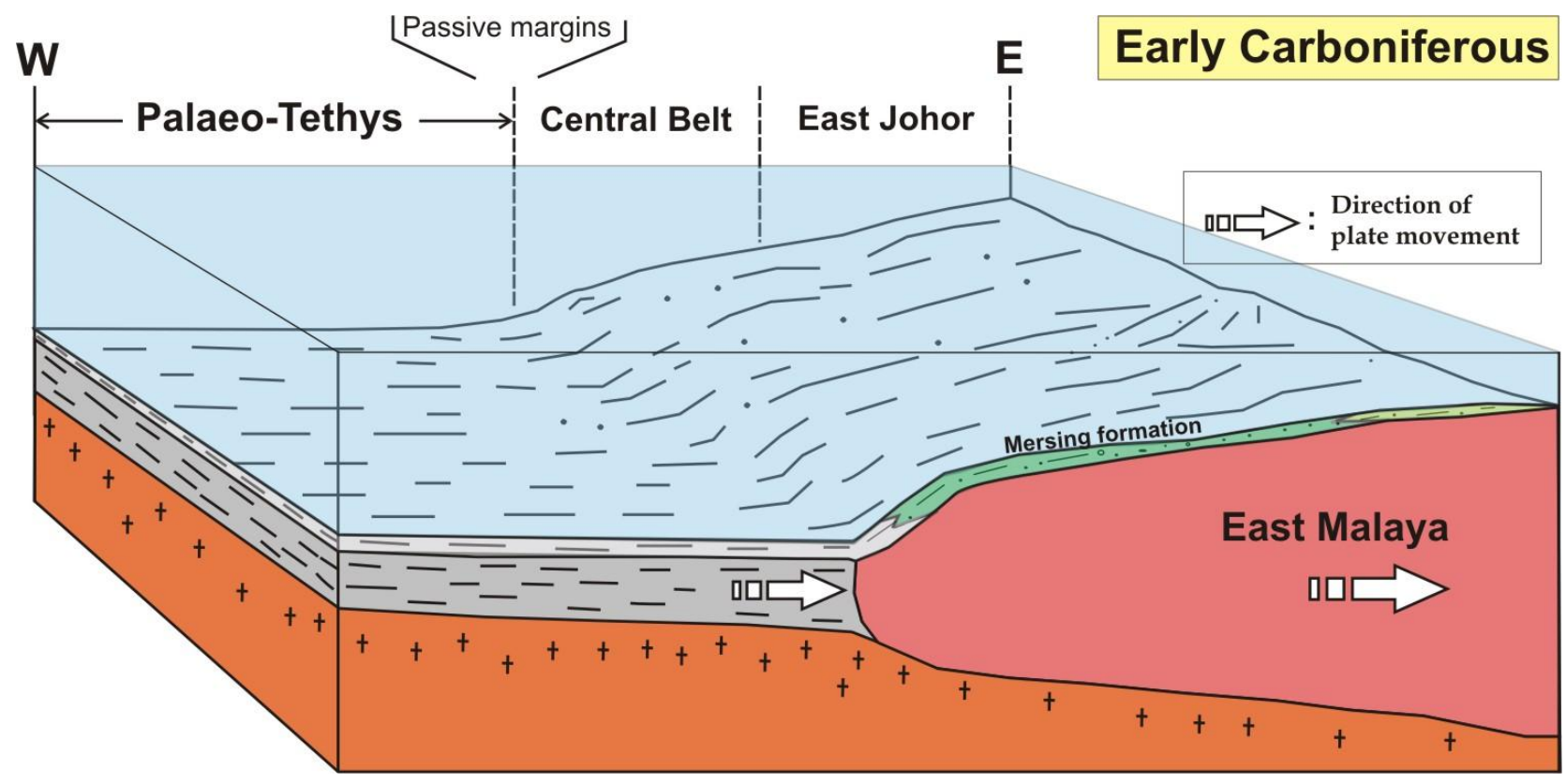

Figure 6: Palaeogeography and tectonic setting of East Johor basin during the Early Carboniferous time. The passive margins occur between the East Malaya and Palaeo-Tethys plates.

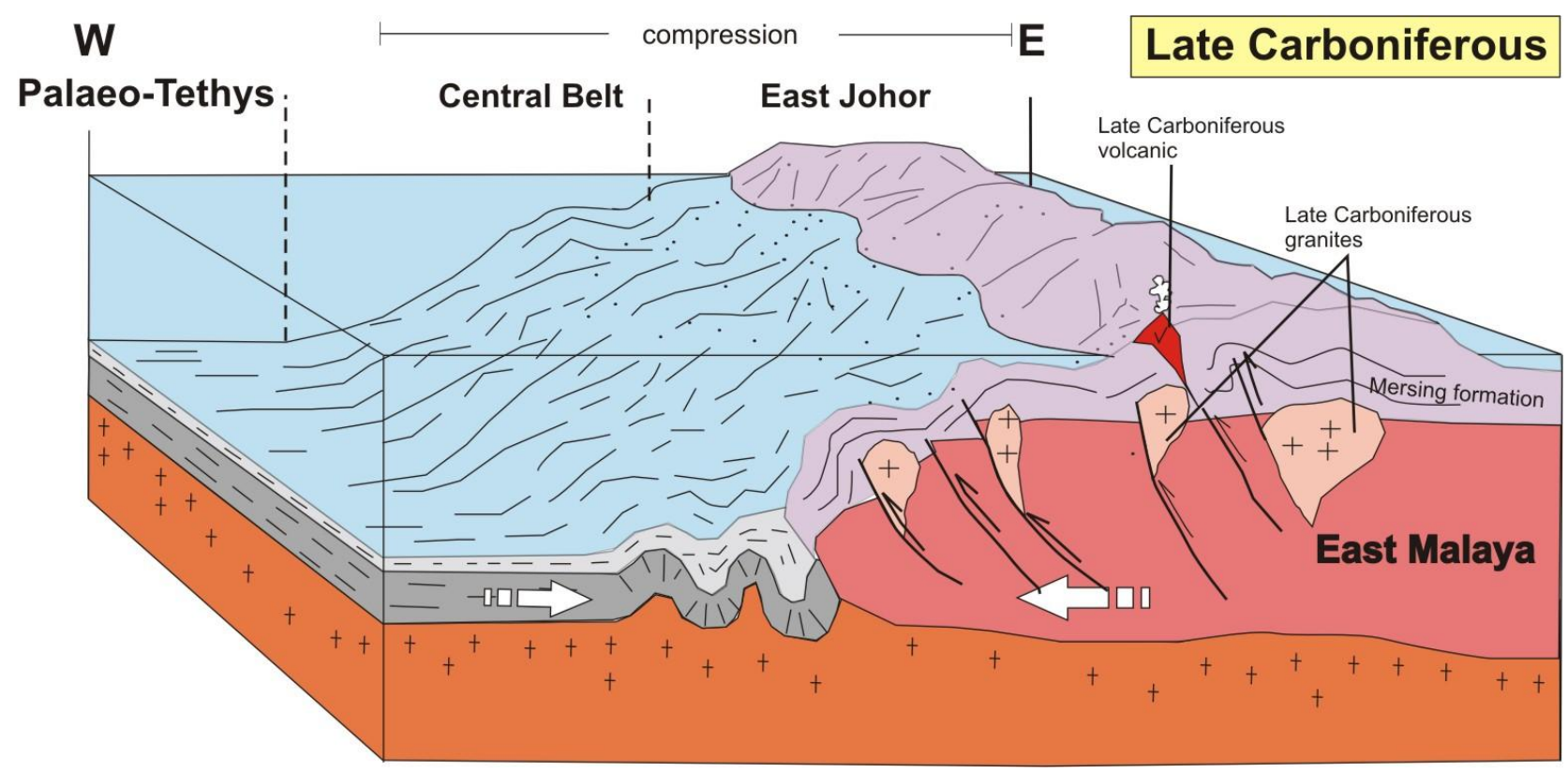

Figure 7: Palaeogeography and tectonic setting of East Johor basin during Late Carboniferous. Palaeo-Tethys pushed the East Malaya continental block generated folding, thrust faulting and uplifting. Granite and volcanic rocks resulted in partial melting and pushed out into Mersing formation through fault systems. Regional metamorphism taken place during this period. 
Wahid. 2006. Struktur dan canggaan Lapisan Mersing di Teluk Bangka, Mersing, Johor. Geological Society of Malaysia Bulletin 49: 85-91.

Hutchison, C.S. 1975. Ophiolite in Southeast Asia. Geological Society of America Bulletin 86: 797806.

Hutchison, C.S. 1989. Geological evolution of Southeast Asia. New York: Oxford University Press.

Johnson, H.D. \& Baldwin, C.T. 1996. Shallow clastic seas. In. Reading, H.G. (ed). Sedimentary environments: Processes, facies and stratigraphy. 3rd ed. pp: 232-280. Oxford: Blackwell Science Ltd.

Koopmans, B.N. 1968. The Tembeling Formation-A Litho-stratigraphic description (West Malaysia). Geological Society of Malaysia Bulletin 1: 23-43.

Liew, T.C. \& McCulloch, M.T. 1985. Genesis of granitoid batholiths of Peninsular Malaysia and implications for model of crustal evolution: Evidence from $\mathrm{Nd}-\mathrm{Sr}$ isotopic and $\mathrm{U}-\mathrm{Pb}$ zircon study. Geochimica et Cosmochemica Acta 49: 587-600.

Malaysian Stratigraphic Nomenclature Committee (MSNC). 1997. Malaysian Stratigraphic Guide . Geological Society of Malaysia Special Publication.

Metcalfe, I. 1999. The ancient Tethys oceans of Asia: How many? How old? How deep? How wide? UNEAC Asia Papers. 1: 1-9.

Metcalfe, I. 2000. The Bentong-Raub suture zone. Journal of Asian Earth Sciences 18: 691-712.

Metcalfe, I. 2002. Permian tectonic framework and palaeogeography of SE Asia. Journal of Asian Earth Sciences 20: 551-566.

Miyashiro, A. 1994. Metamorphic petrology. London: Taylor \& Francis.

Mohd Shafeea Leman, Che Aziz Ali, Kamal Roslan Mohamed, Ibrahim Abdullah, Juhari Mat Akhir \& Suryono, S.S. 2003. Sumber geologi Paleozoik Johor Timur untuk eksploitasi bahan bumi dan pemuliharaan. Prosiding Seminar IRPA RMK-8 Kategori EAR, Jilid II: 26-29.

Mustaffa Kamal Shuib \& Abdul Hadi Abd Rahman. 1999. A five-fold stratigraphic and tectonic subdivision of the Malay Peninsula and the Implications on its tectonic evolutionary history. Proceeding of first seminar-problem \& issues relating to the stratigraphy and tectonic of Peninsular Malaysia. pp. 38-63.

Mutti, E. 1992. Turbidite sandstones. Milano: Agip Instituto di Geologia Universita di Parma.

Pettijohn, F.G., Potter, P.E. \& Siever, R. 1987. Sand and sandstone. 2nd ed. New York: SpringerVerlag.

Raymond, L.A.1995. Petrology. London: Wm.C. Brown Publishers

Suntharalingam, T. 1991. Geology and mineral resources of the Hulu Sedili area, Johor Darul Ta'zim. Geological Survey of Malaysia Map Report 2. 86pp.

Surjono, S.S. 2007. Stratigraphy and Sedimentology of the East Johor Palaeozoic Basin, Peninsular Malaysia. PhD Thesis, Universiti Kebangsaan Malaysia (in prep)

Surjono, S.S, Mohd. Shafeea Leman, Che Aziz Ali \& Kamal Roslan Mohamed. 2006. A review of the Palaeozoic lithostratigraphy of East Johor, Malaysia. Geological Society of Malaysia Bulletin 49: 71-78.

Tajul Anuar Jamaluddin \& Mustaffa Kamal Shuib. 1999. Multiple phase deformational structures in the Tg. Balau, Tg. Lompat and Tg. Siang areas, Desaru Johor, Peninsular Malaysia. Annual Geological Conference 1999-Programme \& Abstract of Papers. 25-26.

Yardley, B.W.D. 1989. An introduction to metamorphic petrology. Essex: Longman Scientific \& Technical. 